\title{
THE INFLUENCE OF STIRRER ON THE DRYING OF WHEAT PARTICLES IN A FLUIDIZED BED AT LOW AIR VELOCITY
}

\author{
Russul A. Kadhim, \\ Ekhlas M. Fayyadh, \\ Sadeq H. Bakhy \\ eng_russul_ak@yahoo.com , ikhlase60@yahoo.com_s_bakhi@yahoo.com \\ University of Technology -Department of Mechanical Engineering-Baghdad-Iraq
}

\begin{abstract}
This study represents an attempt to reduce the drying time of wet grain wheat of the fluidized bed dryer (FBD), using straight blades, and debates the effect of stirrer on the whole drying time at different static bed heights. Experiments for FBD were conducted at the low velocity of air supply $(1.45 \mathrm{~cm} / \mathrm{s})$ with moisture content for grain wheat $12 \%$ and ambient temperature of $37^{\circ} \mathrm{C}$ for each static bed height $(9,12$, and $15 \mathrm{~cm})$. FBD was made from a glass cylindrical column with inside diameter $4.6 \mathrm{~cm}$, outside diameter $(5.2 \mathrm{~cm})$ and length $(116 \mathrm{~cm})$. The results showed an enhancement of (12-20.5\%) in the total drying time for bed height ( 9 and 15) $\mathrm{cm}$, respectively. Also, increasing bed height from $9 \mathrm{~cm}$ to $15 \mathrm{~cm}$ possesses no influence on the equilibrium content of moisture in both techniques of drying either stirred fluidized bed or conventional fluidized bed.
\end{abstract}

Key words: Fluidized bed dryer, Stirrer, Straight blade, Grain wheat

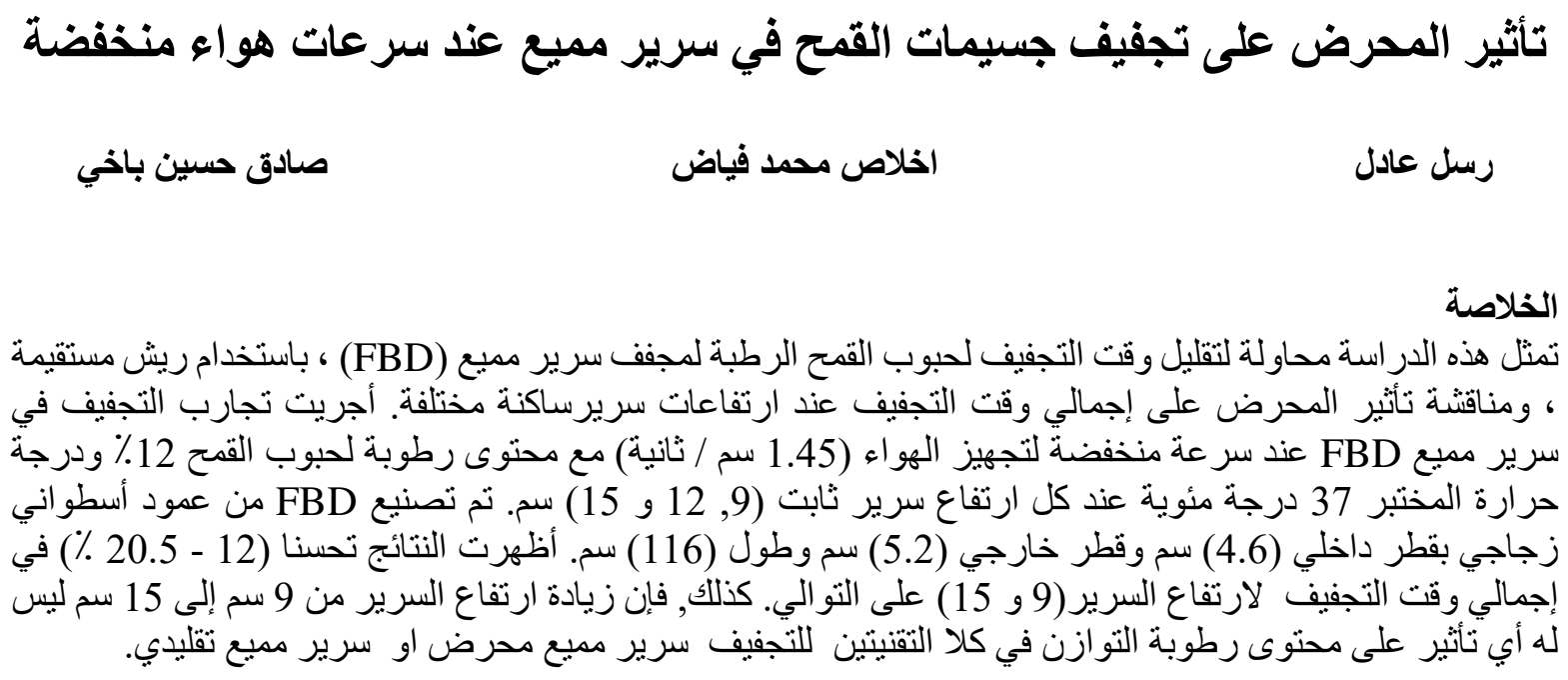

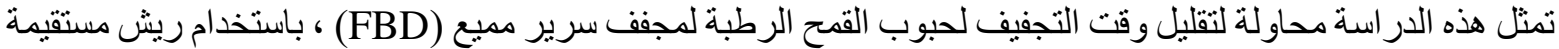

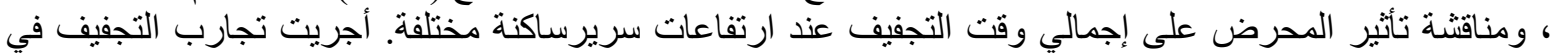

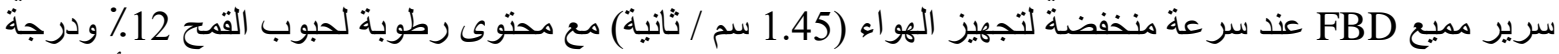

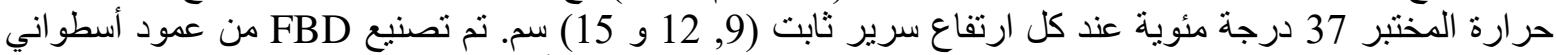

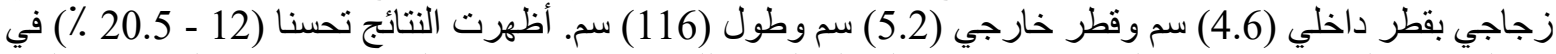

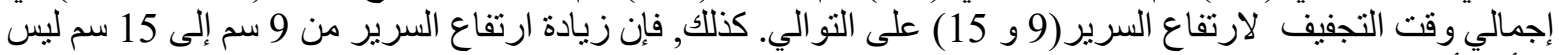

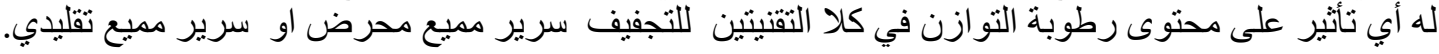


NOMENCLATURE

$\begin{array}{lcc}\text { Item } & \text { Symbol } & \text { Unit } \\ \text { Bed Height } & \mathrm{H} & \mathrm{cm} \\ \text { Density of particle } & \rho_{\mathrm{p}} & \mathrm{kg} / \mathrm{m}^{3} \\ \text { Diameter of sheft } & \text { Dia. } & \mathrm{mm} \\ \begin{array}{l}\text { Distance between two } \\ \text { blades }\end{array} & \mathrm{D} & \mathrm{mm} \\ \text { Inlet air velocity } & \mathrm{U}_{\text {in }} & \mathrm{cm} / \mathrm{s} \\ \text { Lenght of blade } & \mathrm{L} 1, \mathrm{~L} 2 & \mathrm{~mm} \\ \text { Relative Humidity } & \mathrm{RH} & \mathrm{Kg}_{\text {air }} / \mathrm{Kg}_{\text {water }} \\ \text { Thickness of blade } & \mathrm{t} & \mathrm{mm} \\ \text { Width of blade } & \mathrm{W} & \mathrm{mm}\end{array}$

\section{INTRODUCTION}

In many engineering applications, the drying operation is a process that aims to reduce the moisture amount in the majority of biomass products, industrialized or not, to secure their preconservation in the storage and the transport [Keey,1992]. The drying technique is too broadly utilized in various industry branches. [Ambrosio and Taranto, 2002] employed a mechanical anchor shaped stirring paddle on the drying of fine crystalline organic acid particles, which have diameter $80 \mathrm{~mm}$ and density $1.443 \mathrm{~g} / \mathrm{cm}^{3}$. The effects of the primary content of moisture and the drying gas temperature at the bed entrance were evaluated by drying kinetics curves. The result depicted that the produced dried particles had a proper fluidity that can promote the industrial processing continuity, manipulating by hand, transportation, and storing. On the other hand, the traditional fluidized-bed dryers are a feeble selection for processing the residual having a high content of moisture (more than 90\%) of the sludge created in the plants of the municipal wastewater and its intensity for agglomerating through the process of drying. For this reason, [Reyes et al., 2004] investigated using a fluidized-bed dryer with a mechanical excitement and with a lateral flow of air for drying the sludge from a plant of wastewater treatment. Experiments have been done over the temperatures range $\left(80^{\circ} \mathrm{C}\right.$ $\left.110^{\circ} \mathrm{C}\right)$, a rate of stirring $(55 \mathrm{rpm})$ and a velocity of air $(0.9 \mathrm{~m} / \mathrm{s})$ for sludge batches of $(3 \mathrm{~kg})$ with the primary contents of moisture $(0.55$ and $0.65 \mathrm{db})$. It was found that the modification of the fluidized bed had an improvement in the fluidization and an increase in the drying rate. The crystallization process leads to water expulsion resulting in liquid bridges developed among the powder particles which make them cohere together, and the liquid bridges solidification results in the powder caking. For reducing the solid and liquid bridge formation, a stirred fluidized has been used by [Liang and Langrish, 2010] to crystallize the skim powder beyond the spray drying without powders caking. The skim powder possessed a content of moisture (4.6\%) (dry basis). The experiments were carried out at the ambient surrounding of $\left(23 \pm 3^{\circ} \mathrm{C}\right)$ with $(60 \pm 10 \%)$ relative humidity, $(20 \mathrm{l} / \mathrm{min})$ air flow rate and $(34 \mathrm{rpm})$ stirrer rotational speed. Humidity and temperature were governed in a fluidized bed. The authors obtained that the fluidized bed specimens didn't adsorb much water like the original ones, proposing that the fluidized bed specimens were too steady than the original ones. Cassava particles are containing cyanogenic glycosides apt to form the hydrocyanic acid which is poisonous, therefor drying it is inevitable and significant. So, [Oluwaleye and Adeyemi, 2013] experimentally evaluated a batch hot air fluidized-bed dryer for cassava particles. 
Experiments were carried out for a range of temperatures $(60-120)^{\circ} \mathrm{C}$ at three different air flow rates $(0.043,0.05$ and 0.056$) \mathrm{kg} / \mathrm{s}$ in a hot air fluidized-bed dryer for cassava particles with an electric motor and an air heater having a thermostat for selecting the temperature of drying of fluidizing medium. The temperature of drying and the rate of flow were governed via utilizing the controllers of the temperature and the rate of flow rate, respectively. The experiment showed that the time of drying for cassava particles in the dryer reduces with the rise in the temperature of drying. Also, it was noticed that the rate of drying reduces with the rise in the rate of air flow, whereas it rises with the temperature of drying. In a continuous process of paddy drying, the paddy moister content changes all times. So, the required drying process to paddy is for maximizing the drying capacity of the paddy dryer at the minimum loss in the head yield and the minimum consumption of energy without influencing the quality of the rice. Biomass possesses a low density of energy in comparison with the conventional fossil fuels due to the high content of moisture that exceeds (50 wt \%). Such moisture must be reduced to $(8-10 \mathrm{wt} \%)$ before the densification and conversion of energy for the economic utilization. Thus, drying of biomass is required. Therefore, the air velocity influences and temperature of the bed were studied by [Liu et al., 2014] for evaluating the he fluidized-bed dryer performance. Experiments were carried out on a sample of sawdust which divided into two size fractions of (250-355) and (355-500) $\mu \mathrm{m}$ with the primary content of moisture $(20,40$ and $60 \mathrm{wt} \%)$ at various operation conditions, such as the velocity of air from $(0.14)$ to $(0.32) \mathrm{m} / \mathrm{s}$ and the bed temperature of 75,90 and $105^{\circ} \mathrm{C}$. The result depicted that the primary content of moisture of the input sawdust influenced its performance of fluidization for the sawdust drying of a high content of moisture, the behavior of fluidization can be separated into (3) stages; partial fluidization, full fluidization with raising the rate of drying, and full fluidization with reducing the rate of drying. To reduce the time of drying time of a fluidized bed and instantaneously improving the moisture uniformity of wet and adhesive particles (having a primary diameter of around (580) $\mathrm{mm}$ ), [Hoffman et al., 2017] evaluated the positive effect of parameters, such as stirrer design, speed and size on the total drying time to find its optimum. It was found that the whole time of drying to attain the needed content of moisture of the material was a $(63 \%)$ shorter time of drying than for the curve without a stirrer. So., the objective of this work is to investigate the influence of a stirrer on the drying time of the fluidized bed of wet particles of grain wheat and adhesive at different bed heights. [Rosli et al. (2018)] studied numerically the influence of inlet air velocity, inlet air temperature, and particle size on achieving the final moisture ratio of 0.25 of sago waste with the density $(1033 \mathrm{~kg} / \mathrm{m} 3)$ and mass $(600 \mathrm{~g})$ using fluidized bed dryer. However the drying rate and fluidization profile were examined at air velocities of $0.6,1.0,1.3,1.8$, and $2.2 \mathrm{~m} / \mathrm{s}$ and at air temperatures of $50{ }^{\circ} \mathrm{C}, 60{ }^{\circ} \mathrm{C}, 70{ }^{\circ} \mathrm{C}$, and $80^{\circ} \mathrm{C}$ with particle sizes of $200,500,1000$, and $2000 \mu \mathrm{m}$. it was found that increasing the air velocity shortens the required drying time to achieve the desired final moisture ratio. Also, the results were compared with the pervious experimental data.

\section{EXPERIMENTAL WORK Materials}

The experiments were executed using adhesive biomass particles of grain wheat that have an initial diameter of $2 \mathrm{~mm}$, moisture $12 \%$ and density $\rho_{\mathrm{p}} 800 \mathrm{~kg} / \mathrm{m}^{3}$. 


\section{Fluidized bed drying unit}

The test rig schematic diagram as shown in figure (1) includes fluidized bed drying with a controlling system consisting of air compressor that was used for supplying the air to the rig working section during the experiments. The outlet air flow from the compressor is controlled by using an adjustable one-way valve fitted at the compressor drum outlet. The compressor sends the air to a settling chamber (pressure tank), to damp the fluctuations of pressure of the delivery flow and to supply the air at constant pressure. The air volumetric rate of flow to the test rig was measured via an orifice (designed according to B.S.1042) with (9 mm) diameter. U-tube manometer was utilized for measuring the drop of pressure across this orifice. The compressed air was fed to the fluidized bed through the calming section at conical angle $75^{\circ}$ with horizontal. The fluidized-bed dryer has a cylindrical column shape and made of glass enables to be monitored with an internal diameter of $(4.6 \mathrm{~cm})$ and $116 \mathrm{~cm}$ height. Above the fluidized-bed dryer, a top placed D.C. gear motor of (300 Watt) capacity was utilized for coupling the stirrer type coaxial straight blade. Figure (2) reveals the schematic design drawing of stirrer. The ratio of its diameter to the diameter of the fluidized bed dryer is (0.95), [Nielsen, 1974]. The output unit is governed automatically via the voltage variation utilizing a governing regime. At the bottom of the fluidized-bed dryer, there is a distributor plate having (37) holes each with a diameter of $1 \mathrm{~mm}$, forming a total open area of $1.74 \%$ of fluidized bed. Over the distributor, a screen for a uniform distribution of air was utilized. For measuring the drop of pressure through the fluidized bed, two pressure taps were provided using analog reader sensor type (6CE6D/201518Y) for range 1 bar with accuracy of $(0.26 \%)$. One of these pressure tap was located at the upstream of distributor, while the other was at a location of $77.5 \mathrm{~cm}$ downstream of distributor. Two digital signal sensors module (DHT11AM2303 with accuracy \pm 0.1 ) were used for measuring the relative Humidity (RH) and temperature of air at the inlet and outlet of the fluidized bed. The outlet sensor was located at the fixed height of fluidized bed $(85 \mathrm{~cm})$ above the distributor. Experiments were carried out for weighing the biomass particles ranging from $(100,150$, and $200 \mathrm{~g})$ with bed height $(\mathrm{H})(9$, 12 , and $15 \mathrm{~cm})$ and inlet air velocity $\mathrm{U}_{\text {in }}$ of $(1.45 \mathrm{~cm} / \mathrm{s})$. The initial content of moisture of the specimen was $(12 \%)$, and speed of stirrer was $(70 \mathrm{rpm})$ for each static bed height.

\section{CONTROL UNIT}

The most desirable control of the output variables in the stirred fluidized-bed dryer is the moisture content of the product. Frequently, the content of moister of the dried product can be deduced from the humidity and temperature of the exhaust air. So, DHT sensors were used to sense the air relative humidity at the inside and outside of the fluidized column. This difference, $\Delta \mathrm{RH} \mathrm{PV}_{\mathrm{V}}$, represents the process variable, $\mathrm{PV}$, which is important to maintain under the control of signal input and signal output of the present automatic feedback control, as shown in figure (3). The desired value of the $\Delta \mathrm{RH} P \mathrm{PV}$ is $\Delta \mathrm{RH}_{\mathrm{SP}}$ (the difference of relative humidity at set point), which was adjusted at $2 \%$, and the difference between the relative humidity of $\Delta \mathrm{RH} \mathrm{H}_{\mathrm{PV}}$ and $\Delta \mathrm{RH}$ SP is represented by the error (e) magnitude. The speed of stirrer is read by Hall sensor mounted on a D.C. motor, which actuated the stirrer. The D.C. motor was controlled by programing the Arduino that is used to set the duty-cycle of a PWM pulse train suitable for the output speed.

\section{EXPERIMENT PROCEDURE}

The experimental work has been carried out according to the following procedure 1.Switch the main power supply on in order to operate all instruments in the test rig.

2. Check the compressed air in the pressure tank to ensure it contains enough amounts to start the experiments. If there is not enough compressed air in the pressure tank, turn the 
compressor on to fill the pressure tank with compressed air, then closed. Note that, the pressure in tank is 4 bar.

3. To provide the desired static bed height, put sufficient wet biomass in the fluidized column.

4. Open the valve gradually between pressure tank and test rig until reaching the desired speed $(1.45 \mathrm{~cm} / \mathrm{s})$. The desired speed can be detected from pressure drop measurement across the orifice.

5. Turn the computer ON, and then put the Arduino program ON.

6. Switch the power supply on to the controller circuit that supplies the power to the stirrer motor. However, the stirrer speed will be increased to the desired speed setting on the control circuit which was 70 r.p.m.

7. Run the Arduino program, then data for air velocity, time, relative humidity and temperature at inlet and outlet of fluidized column, and stirrer speed with duty cycle pulses are recorded.

8. Watching the pressure drop across the distributer and pressure drop across the orifice during the experiment.

9. The stirrer was stopped when the difference of the relative humidity value approached to zero, after that, the air flow rate was stopped and the power supply was turned OFF.

10. Each test is carried out about four times for readability check.

\section{RESULT AND DISCUSSION}

The drying process is similar for each kind of fluidized-bed dryer that is a conventional, stirred and vibrated. So, it will be mentioned once at section conventional fluidized-bed dryer.

\section{Conventional Fluidized-Bed Dryer}

The drying process of wet biomass for the conventional fluidized-bed dryer at the bed height $(9,12$, and $15 \mathrm{~cm})$ shown in figures $(4 \mathrm{~A})$ to $(6 \mathrm{~A})$ has been done at constant parameters as $37^{\circ} \mathrm{C}$ temperature of air with a low velocity of $1.45 \mathrm{~cm} / \mathrm{s}$, a particle with $2 \mathrm{~mm}$ diameter and initial moisture content for the biomass particle is $12 \%$. In general, in each run test for changing the value of static bed height, it is noted in these figures that the value of moisture at point $(\mathrm{O})$ is the lowest one and then increased gradually to point $(\mathrm{A})$, this is most likely caused by placing a fresh wet particles into the fluidized bed dryer, hence the incoming dry air leads to evaporate the surface moisture on the wet particles and saturate a humidity sensor. This period is called sensor response and it's increased with raising the static bed height. In the period $A$ to $D$, the process of drying can be separated into (3) parts: The first one is the warmed-up period (A-B), as seen in figures (4A) (5A) (6A), during this period, the material start to heat from the initial temperature to the wet bulb temperature, i.e. the heat of air is consumed to evaporate the moisture from the material surface, so the concentration of water decreases. While second one is the constant rate period (B-C), during such period, the air temperature stays fixed at air wet bulb temperature, i.e. the added heat is consumed by evaporation of the free water to the layer that is adjacent to the surface of biomass. Then, for the critical content of moisture $(\mathrm{C})$, it's a transmission point between fixed rate period and third period (falling rate period, C-D), however at point (C), the material surface dries up, and the drying rate starts to reduce. Then, the air temperature is rising during the falling period. If the drying is continued for enough time, the value attains the equilibrium content of moister (D), and it is impossible to dry the material more than under the actual condition. These figures also show the effect of the bed height, thus, as the height of the bed reduces, the process of drying accelerates owing to the decreases in weight solid, and the time of drying becomes shorter. As well, the critical moisture content decreases while increasing the constant 
rate drying period with the decreases in the height of the bed but it possesses no influence upon the equilibrium content of moisture. Table (1) shows the moisture content of air and the constant rate period during the drying process.

\section{Stirred Fluidized Bed Dryer:}

The effect of stirred on the drying process of biomass for three different static bed heights ( 9 , 12 , and 15$) \mathrm{cm}$ can be shown in figures (4B) to (6B). The inlet air temperature, inlet air velocity, stirred speed, diameter of the particle, and moisture content of particles were kept constant at $37^{\circ} \mathrm{C}, 1.45 \mathrm{~cm}, 70 \mathrm{rpm}, 2 \mathrm{~mm}$ and $12 \%$. It has been observed in these figures that as the static bed height is increased, the time period of response sensor increased slightly, for example: from 0 to $76 \mathrm{sec}$ for static bed height $9 \mathrm{~cm}$ and from 0 to $90 \mathrm{sec}$ for static bed height $15 \mathrm{~cm}$. However, from the comparison of these curves with the curves of conventional during this period, it is observed that there is a positive influence of stirrer upon the adhesive layer, where the important reduction in time is $70 \%$ for the bed height $9 \mathrm{~cm}$ and $80 \%$ for the bed height $15 \mathrm{~cm}$. In the period of drying process (i.e. A to D), as seen in figures, the time of drying was obtained to raise from (2046) sec to (2810) sec as the bed height was increased from $9 \mathrm{~cm}$ to $15 \mathrm{~cm}$, respectively. This may be interpreted via noticing that the higher height, the bigger mass loading of solid inventory, the bigger the overall moisture exists in fluidized bed. Since the flow rate of air stayed same for the whole three heights of bed, the time of drying was anticipated to increase with an increment in the bed height. As comparing this period with the conventional, it was found that the drying time is reduced from (12)\% for bed height $9 \mathrm{~cm}$ to $(20.5) \%$ for bed height $15 \mathrm{~cm}$. This is due to the existence of the stirrer that has moved the wet particles adhering in the fluidized bed, therefore the particles adhesive layer is disturbed, resulting in a more homogenous flow of the drying air during the layer. This outcome is an essential reduction in the time of drying.

\section{VERIFICATION OF PRESENT WORK:}

Experiments data for the conventional and inverted bed dryer from the current work were compared with the experiment data of [Bait G. R. et al., 2011], as shown in Figure 7. From the figure, it can be seen that the current results have a similar behavior to [Bait G. R. et al., 2011], with respect to drying time period that was shorter for stirrer fluidized bed dryer as compared to the conventional fluidized bed.

\section{CONCLUSIONS}

The results of the study of stirring fluidized bed showed that:

1. The stirrer adopted in this study was a positive influence on the time of drying of the wet grain wheat particles through the process of drying in the fluidized bed layer. The enhancement in the total drying time was $(12 \%-20.5 \%)$.

2. There is a positive influence of stirrer upon the time period (O-A) of the moisture response sensor for the biomass, where the significant reduction in time was $70 \%$ for the bed height $9 \mathrm{~cm}$ and $80 \%$ for the bed height $15 \mathrm{~cm}$ as compared to the conventional fluidized bed.

3. Increasing bed height from $9 \mathrm{~cm}$ to $15 \mathrm{~cm}$ possesses no influence upon the equilibrium content of moisture in both dryer techniques either stirred fluidized bed or conventional fluidized bed. 
4. The reduction of total drying time for stirred fluidized bed was (12)\% for the bed height $9 \mathrm{~cm}$ and (20.5)\% for the bed height $15 \mathrm{~cm}$ as compared with the conventional fluidized bed.

5. The constant rate period decreased with increasing the height of bed. Also, it decreases in general by increasing the primary concentration of moisture. However, this period for the stirred fluidized bed is shorter than that for the conventional fluidized bed.

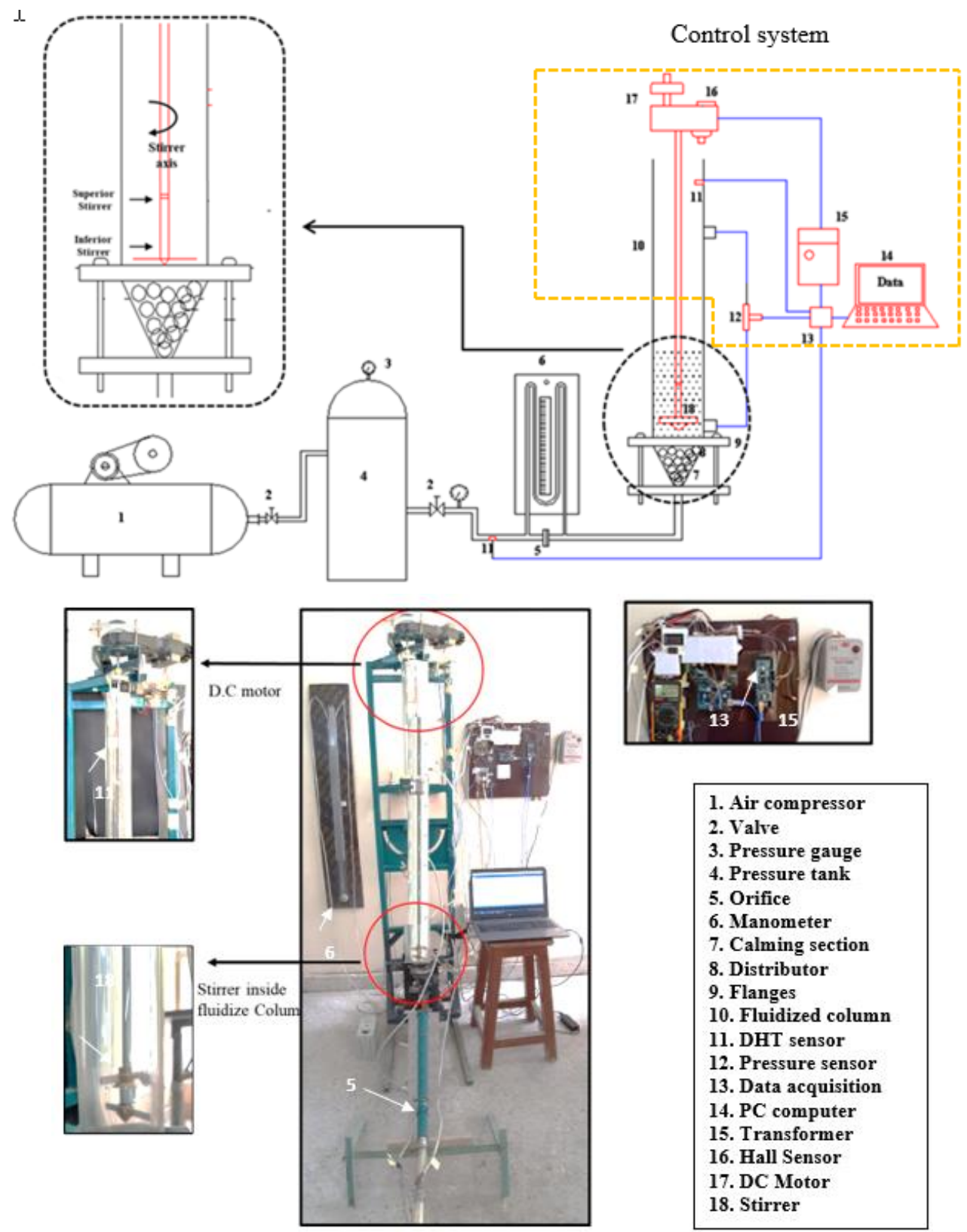

Fig. (1) The schematic diagram and the test rig of the stirred fluidized-bed dryer 


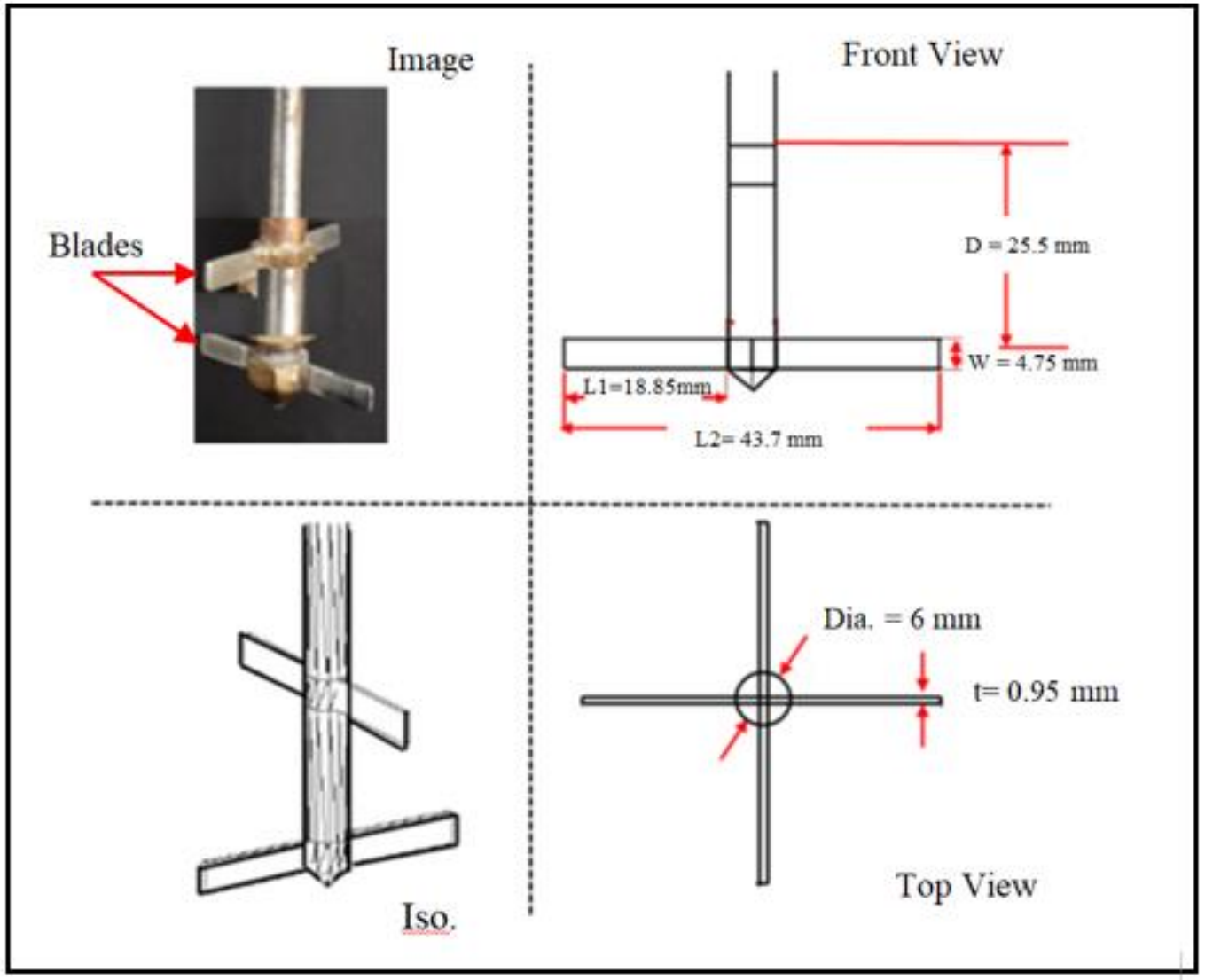

Fig. (2) Dimensions of stirrer

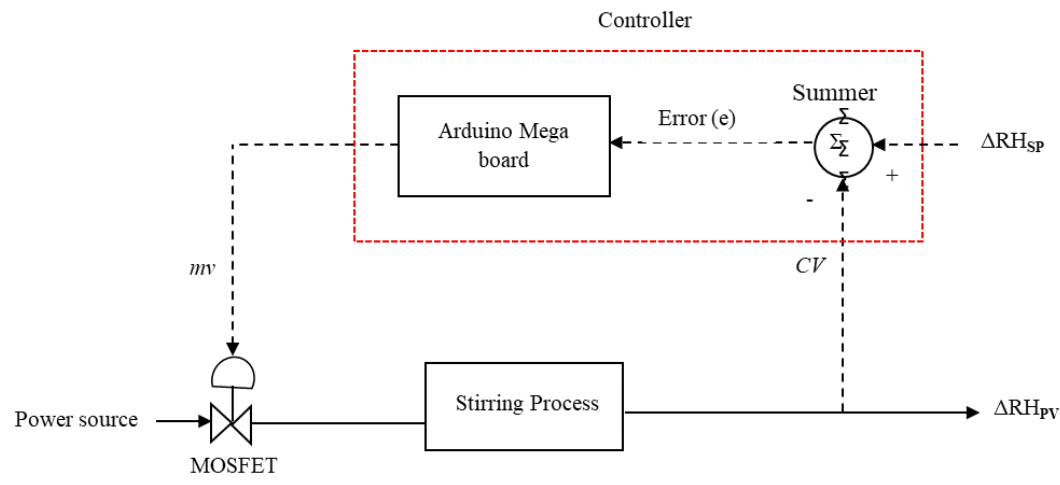

Fig. (3) Feedback control loop schematic for the stirred fluidized-bed dryer 
Table (1) The effect of static bed height on the moisture content for the conventional and stirred fluidized bed

\begin{tabular}{|c|c|c|c|c|c|c|}
\hline $\begin{array}{l}\text { Bed } \\
\text { height } \\
(\mathrm{cm})\end{array}$ & Type & $\begin{array}{c}\text { Initial } \\
\text { moisture } \\
\text { content at } \\
\text { point }(\mathrm{A}) \\
m_{\tilde{i}} \\
\left(\mathrm{~g}_{\text {water }} / \mathrm{kg}_{\text {air }}\right)\end{array}$ & $\begin{array}{c}\text { Critical } \\
\text { moisture } \\
\text { content at } \\
\text { point }(\mathrm{C}) \\
m_{\epsilon} \\
\left(\mathrm{g}_{\text {water }} / \mathrm{kg}_{\text {air }}\right)\end{array}$ & $\begin{array}{c}\text { Equilibriu } \\
\mathrm{m} \text { moisture } \\
\text { content at } \\
\text { point }(\mathrm{E}) \\
m_{e} \\
\left(\mathrm{~g}_{\mathrm{water}} / \mathrm{kg}_{\text {air }}\right)\end{array}$ & $\begin{array}{l}\text { Time } \\
\text { at Point } \\
\text { (B-C) } \\
\text { (sec.) }\end{array}$ & $\begin{array}{c}\begin{array}{c}\text { Constant rate } \\
\text { period }\end{array} \\
\frac{m_{i j A}-m_{c) C}}{t_{R-C}} \\
\left(\mathrm{~g}_{\text {water }} / \mathrm{kg}_{\text {air }} \cdot \mathrm{sec}\right)\end{array}$ \\
\hline \multirow[t]{2}{*}{9} & $\begin{array}{l}\text { Conventional } \\
\text { Fluidized Bed }\end{array}$ & 12.9 & 6.3 & 0.77 & $520-1150$ & $10.4761 * 10^{\wedge}-3$ \\
\hline & $\begin{array}{c}\text { Stirred } \\
\text { Fluidized Bed }\end{array}$ & 12 & 7.1 & 0.71 & $250-850$ & $8.1666 * 10^{\wedge}-3$ \\
\hline \multirow[t]{2}{*}{12} & $\begin{array}{l}\text { Conventional } \\
\text { Fluidized Bed }\end{array}$ & 15.9 & 8.7 & 0.78 & $990-1750$ & $9.4736^{*} 10^{\wedge}-3$ \\
\hline & $\begin{array}{c}\text { Stirred } \\
\text { Fluidized Bed } \\
\end{array}$ & 15 & 9.1 & 0.73 & $360-1020$ & $8.9393 * 10^{\wedge}-3$ \\
\hline \multirow[t]{2}{*}{15} & $\begin{array}{c}\text { Conventional } \\
\text { Fluidized Bed } \\
\end{array}$ & 17.9 & 9.3 & 0.79 & $1160-2100$ & $9.1489 * 10^{\wedge}-3$ \\
\hline & $\begin{array}{c}\text { Stirred } \\
\text { Fluidized Bed }\end{array}$ & 17 & 10.3 & 0.75 & $450-1290$ & $7.9761 * 10^{\wedge}-3$ \\
\hline
\end{tabular}

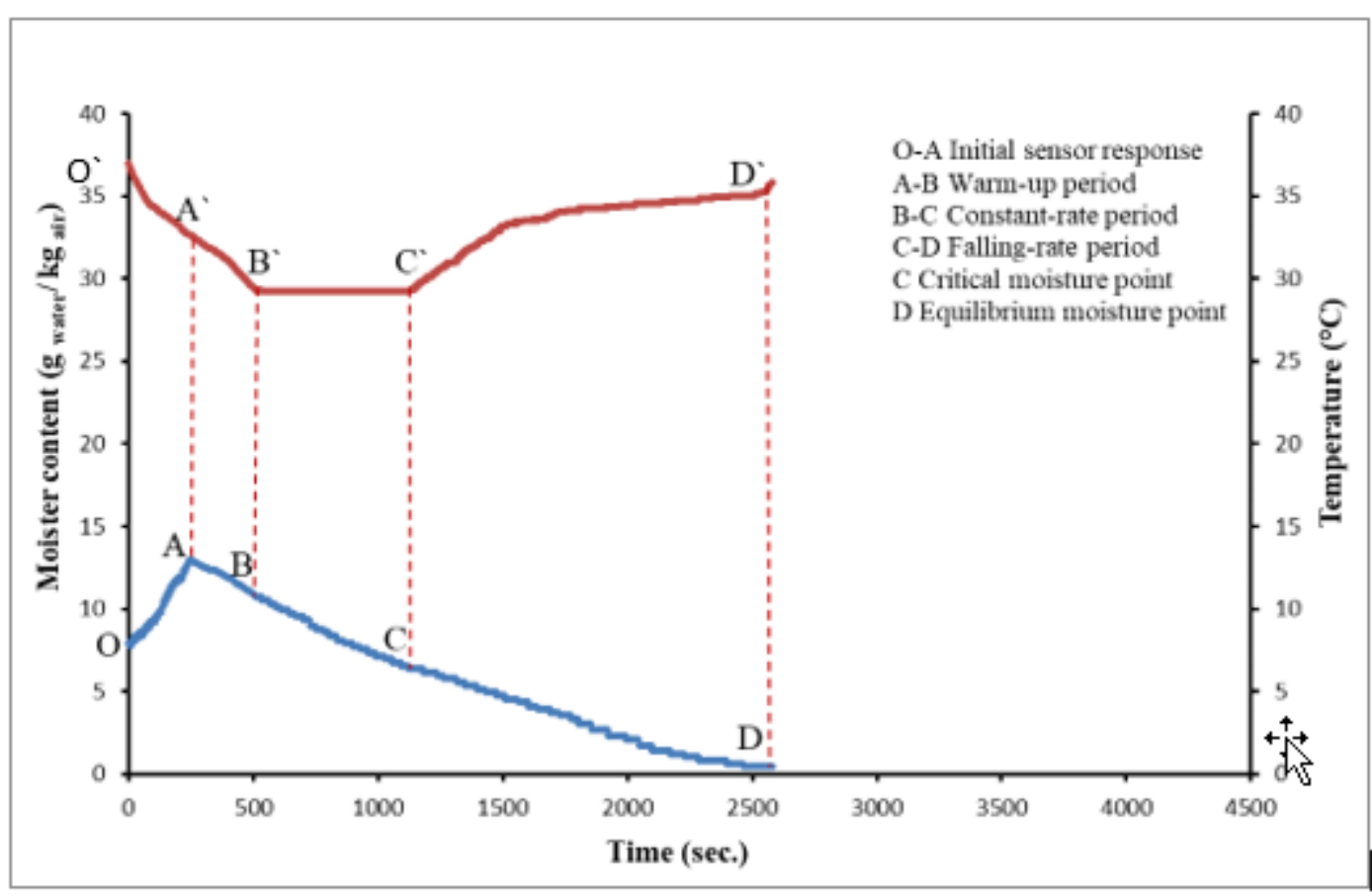

a. The conventional fluidized-bed dryer 


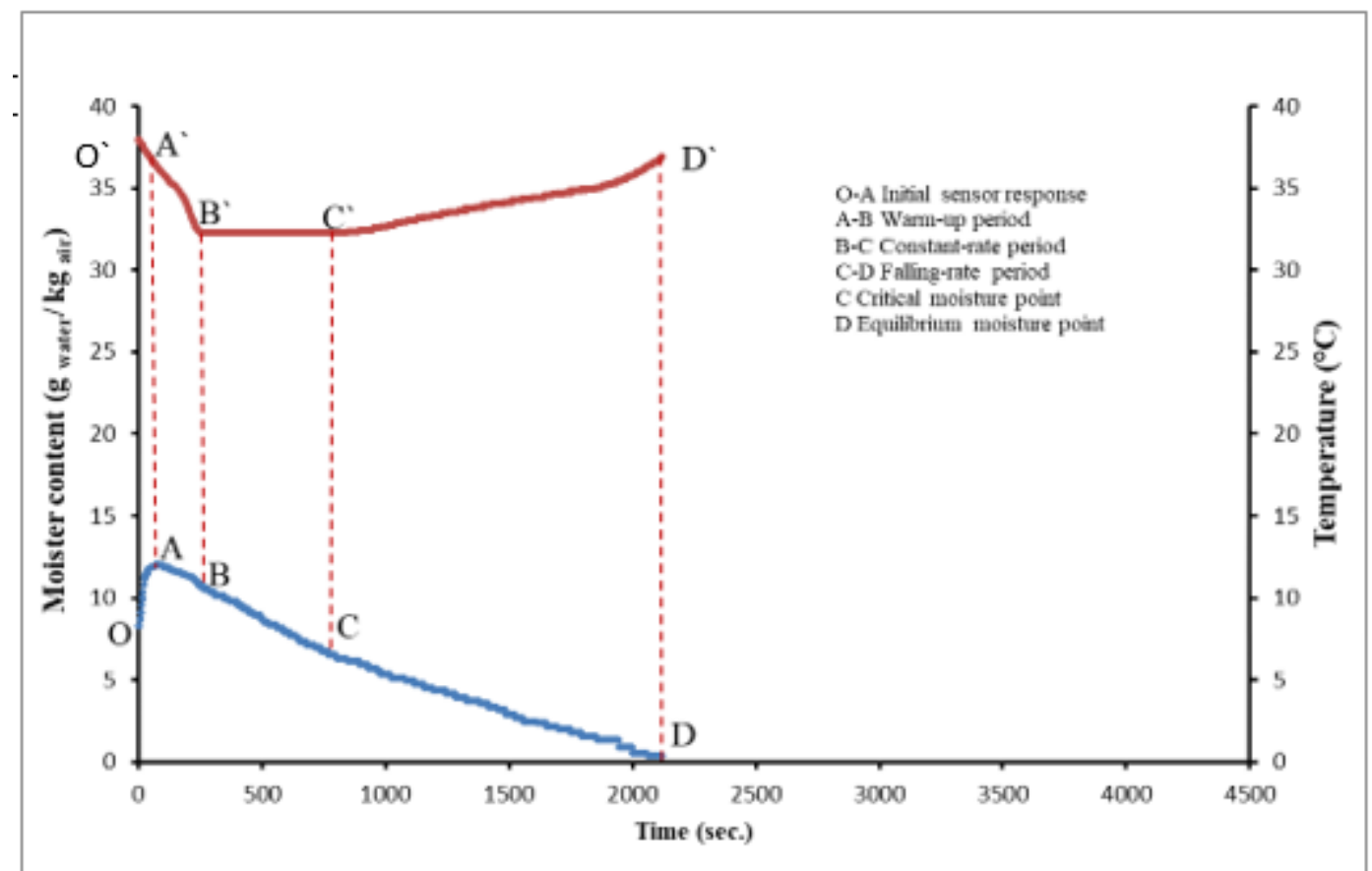

b. The stirred fluidized-bed dryer

Fig. (4) The drying time of the conventional and stirred fluidized-bed dryer at bed height $9 \mathrm{~cm}$

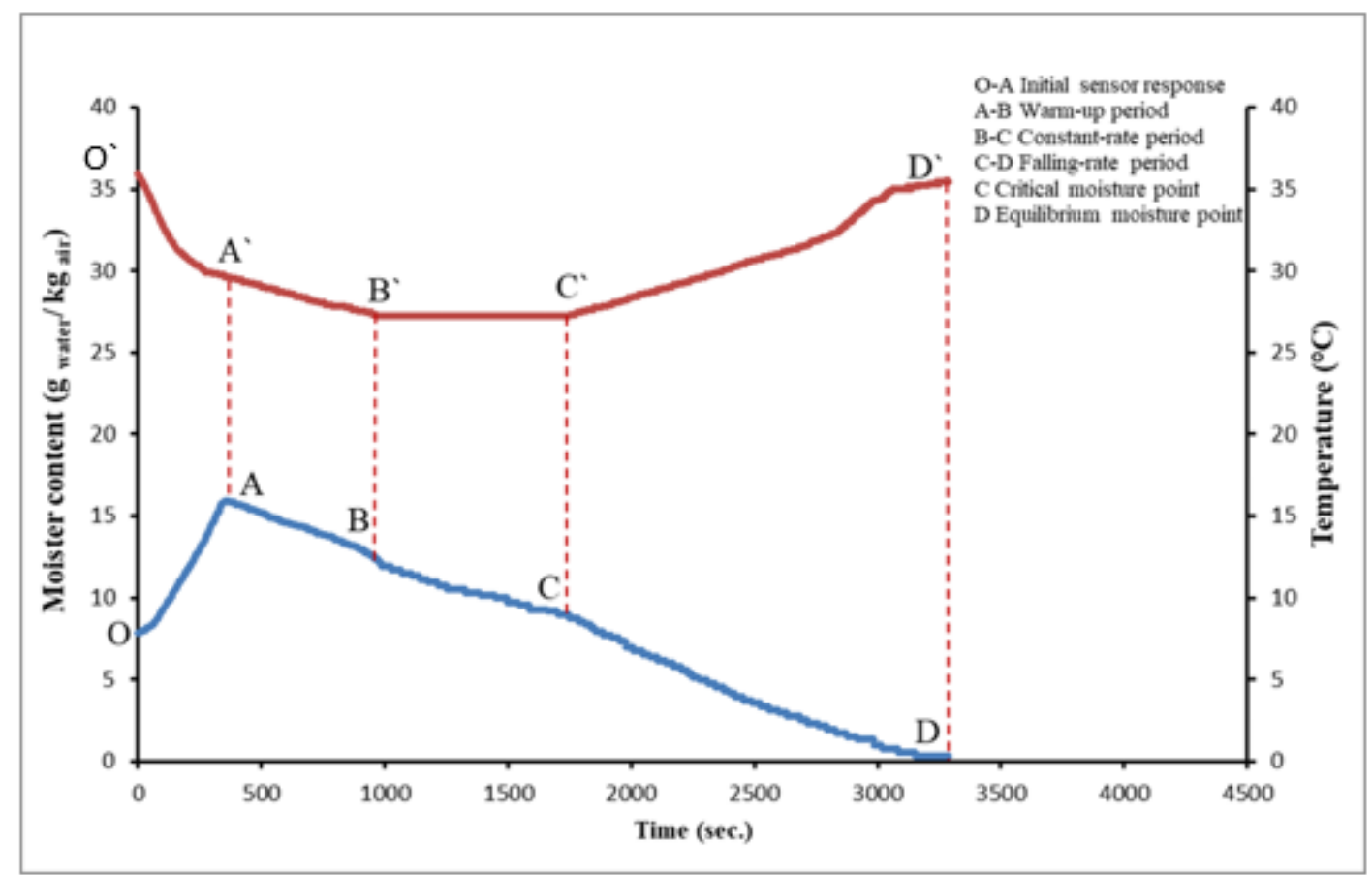

a. The conventional fluidized-bed dryer 


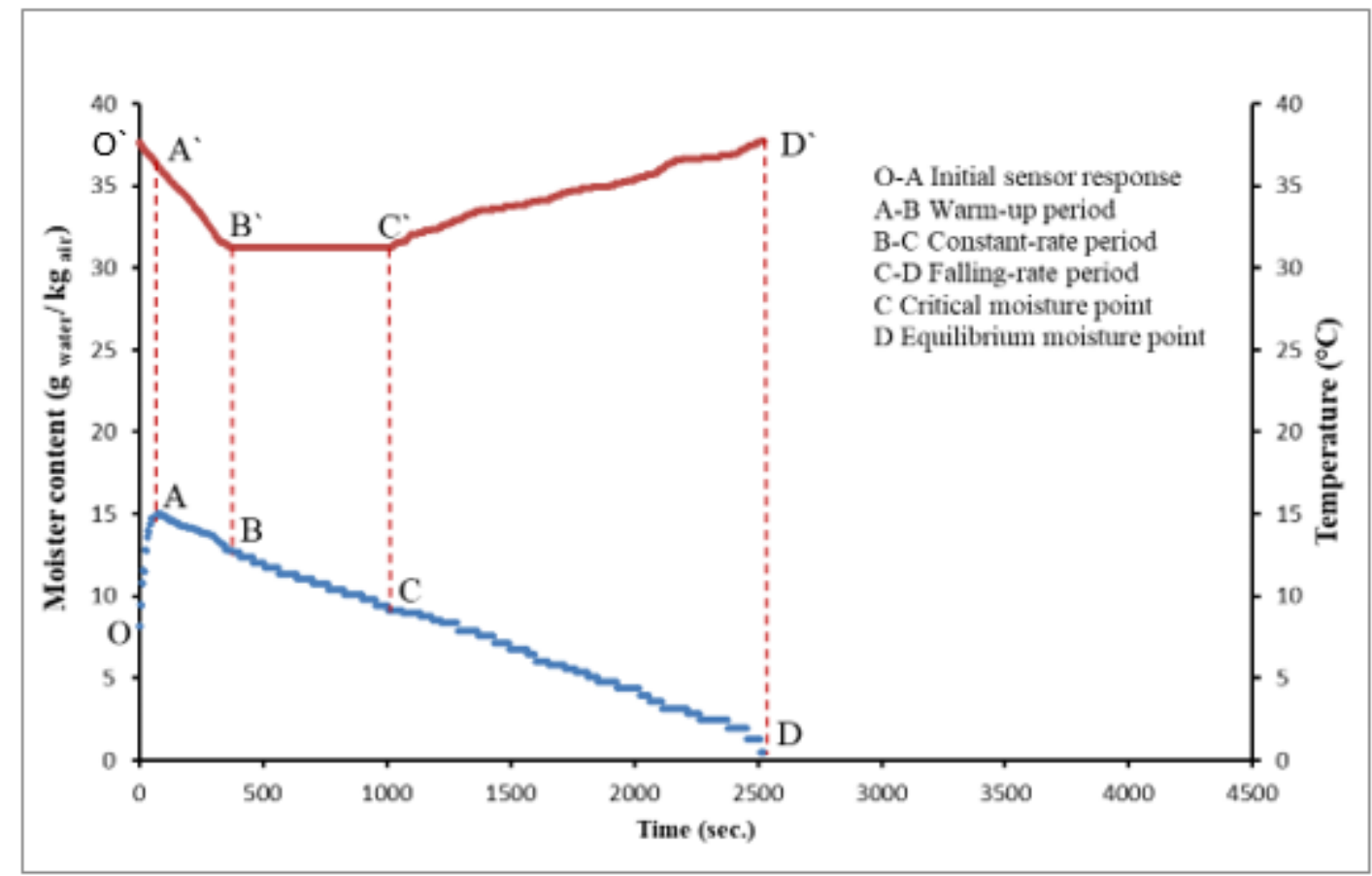

b. The stirred fluidized-bed dryer

Fig. (5) The drying time of the conventional and stirred fluidized bed dryer at bed height $12 \mathrm{~cm}$

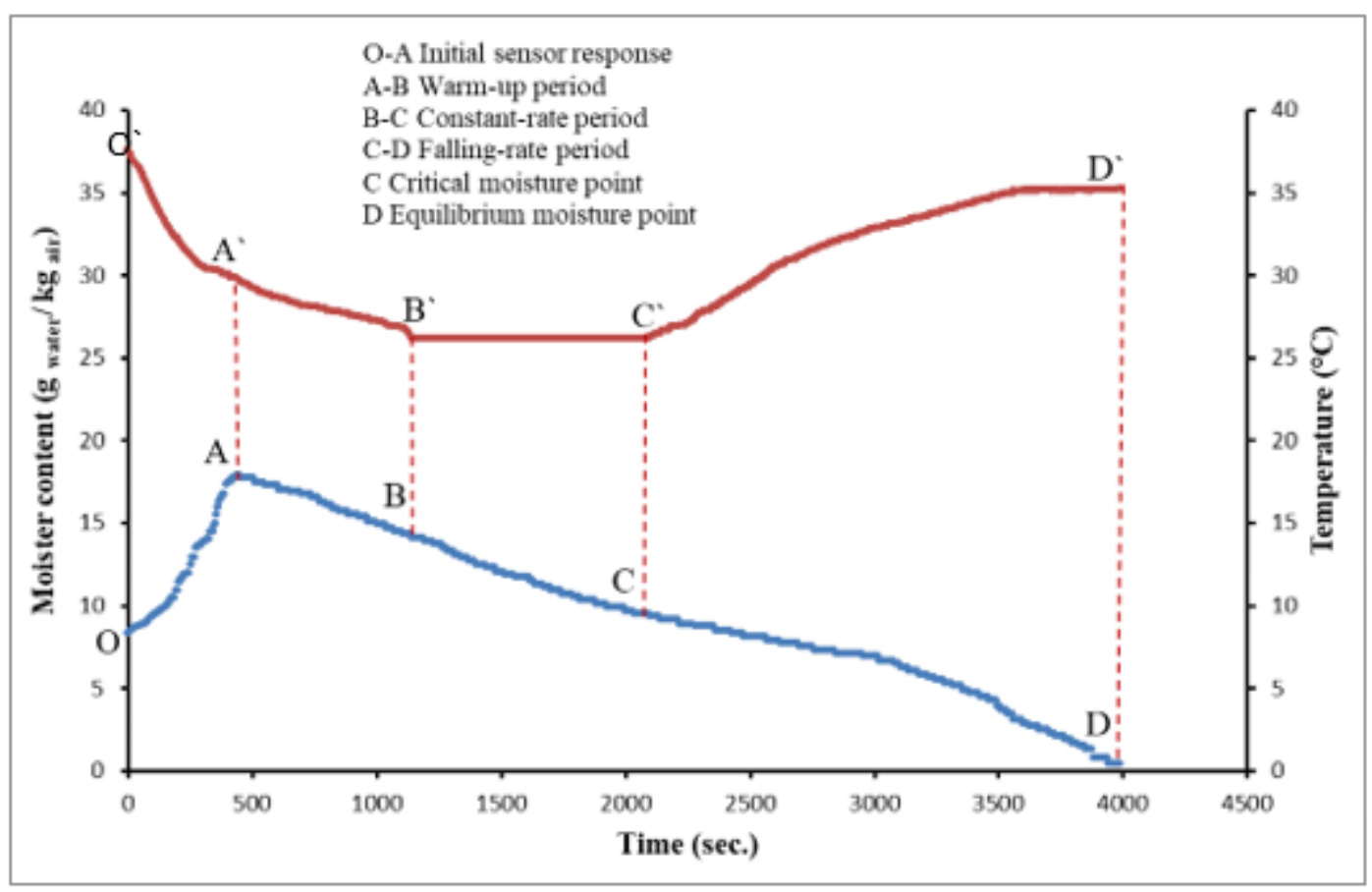

a. The conventional fluidized-bed dryer 


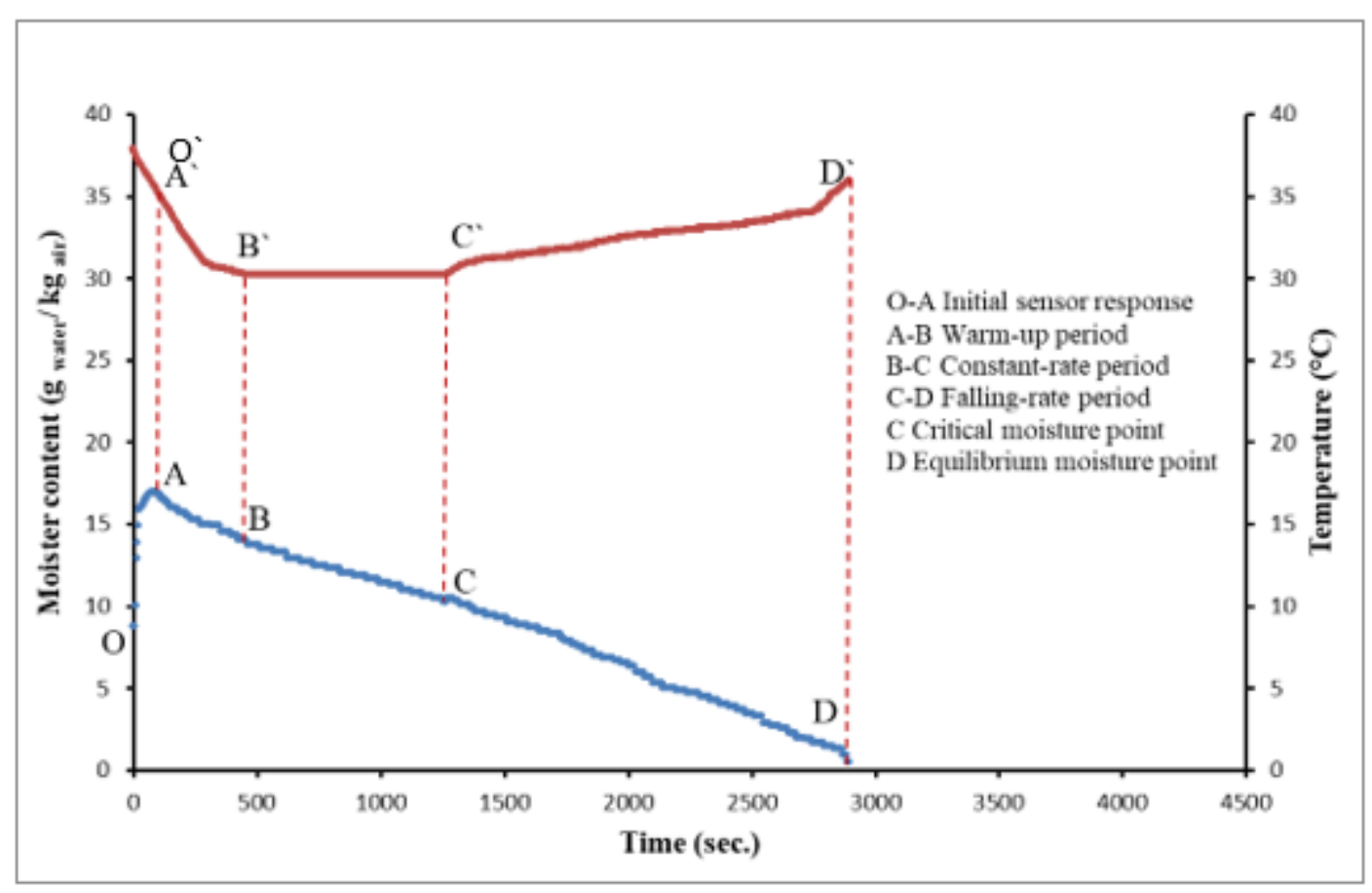

b.The stirred fluidized-bed dryer

Fig. (6) The drying time of the conventional and stirred fluidized bed dryer at bed height $15 \mathrm{~cm}$.
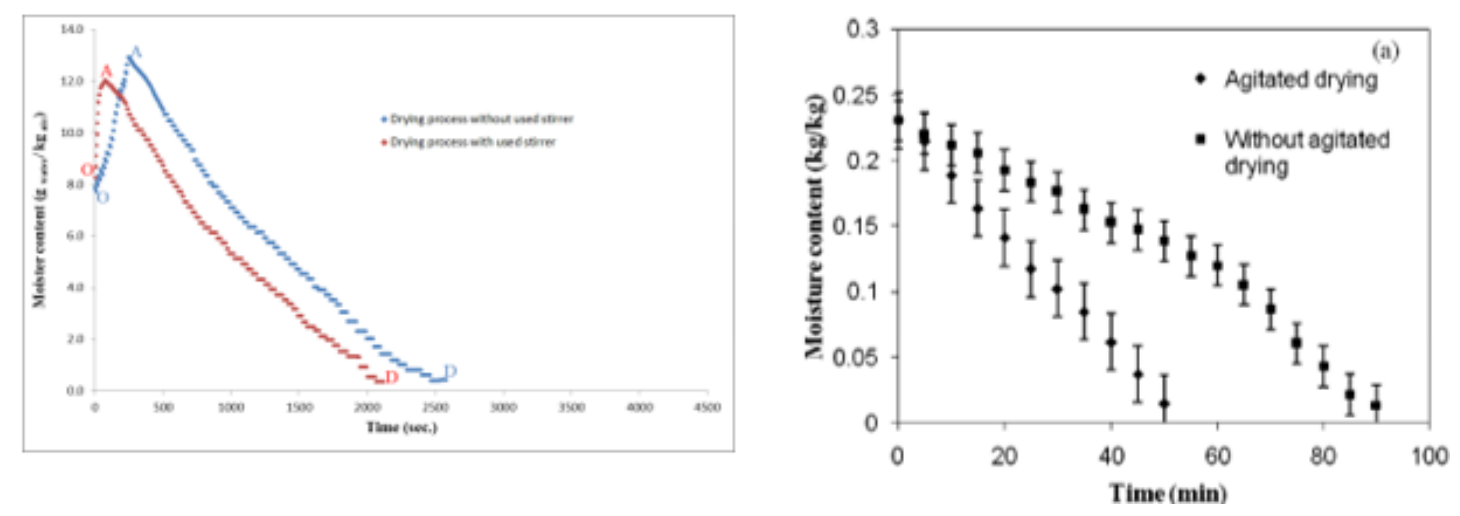

a.Present work of drying curves at bed height $9 \mathrm{~cm}$ (mass loading $=100 \mathrm{~g}$ )
b.Resulting drying curves of [Bati G. R. et al. 2011] at feed loading $=10 \mathrm{~kg}$.

Fig. (7) validation of present work 


\section{REFERENCES}

Ambrosio M. C. B. and Toranto O. P., (2002), "The drying of solids in a modified fluidized bed", Brazilian Journal of Chemical Engineering, P.P. 355-358.

Bait G. R., Pawar B. S., Banerjee N. A., Mujumdar S. A., and Thorat N. B. (2011), "Mechanically agitated fluidized bed drying of cohesive particles at low air velocity", International Journal of Drying Technology, pp. 808-818.

Hoffman P., Penicka M., and Fort I., (2017), "Effect of fluidized bed stirring on drying process of adhesive particles", Chem, Biochem Eng., P.P. 1-10.

Keey R. B. (1992), "Drying of Loose and Particulate Materials", New York: Hemisphere Publ., P.P. 29-32.

Liang Z. and Langrish T., (2010) "Control of crystallization and caking of skim milk powder in fluidized beds”, A preliminary study, Dairy Journal, P.P. 345 -353.

Nielsen R. H., (1974), "Particle mixing and circulation in gas fluidized beds of flour and starch", Theses and Dissertations, State University, USA.

Oluwaleye I. O., B. M. Adeyemi, (2013), "Experimental evaluation of a bitch hot air fluidized bed dryer", International journal of modern engineering research (IJMER), Vol. 3, Issue 1, Jan-Feb 2013, P.P. 497-503.

Reyes A., Eckholt M. and Alvarez I. P. (2004), "Drying and Heat Transfer Characteristics for a Novel Fluidized Bed Dryer", Drying Technology, P.P. 1869-1895.

Rosli I. M., Abdul Nasir A., Takriff S. M. and Chern P. L. (2018), "Simulation of a Fluidized Bed Dryer for the Drying of Sago Waste”, Energies/ MDPI journal . 